
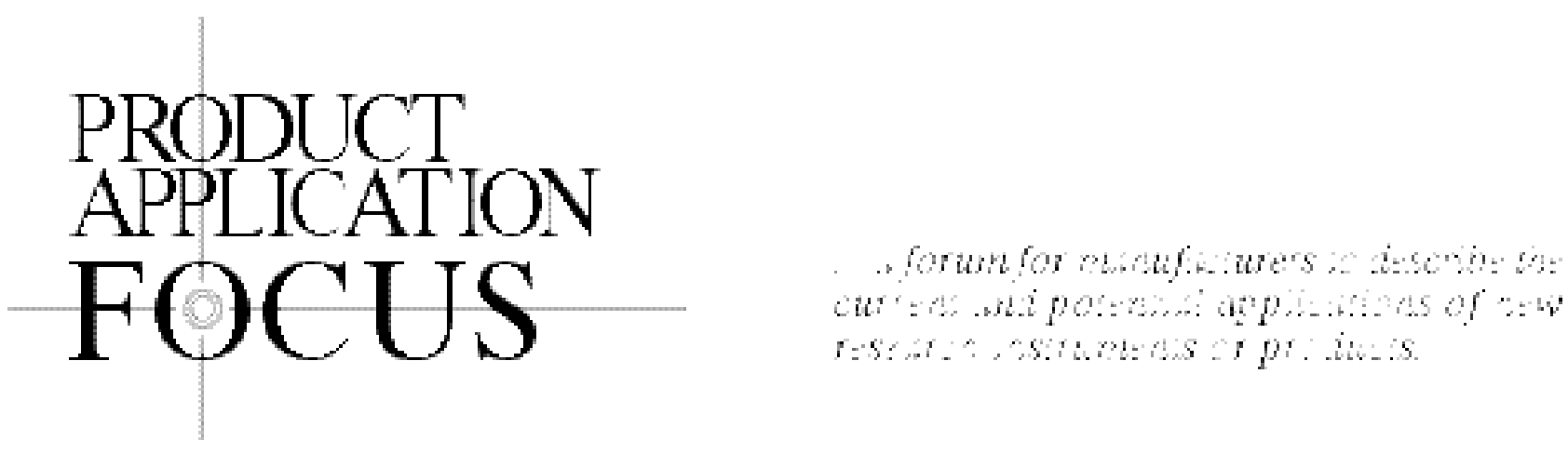

\title{
PCR-Based Detection of Genetically Modified Soybean and Maize in Raw and Highly Processed Foodstuffs
}

\author{
C. Tengel, P. Schüßler ${ }^{1}$, E. Setzke ${ }^{1}$, J. Balles, and M. Sprenger-Haußels ${ }^{1}$ \\ Labor L+S AG, Bad Bocklet, and ${ }^{1}$ QIAGEN GmbH, Hilden, Germany
}

BioTechniques 31:426-429 (August 2001)

\begin{abstract}
The PCR method has proved to be an invaluable tool for the specific and sensitive detection of genetically modified material (e.g., Roundup Ready ${ }^{\mathrm{TM}}$ Soybean and Bt-176 "Maximizer" Maize) in foodstuffs. The first step in the procedure, namely the purification of nucleic acids from the sample, is often the deciding factor in the production of meaningful results. In this study, we present two procedures that enable an efficient isolation of trace amounts of genetic material from both raw and highly processed foodstuffs. We show that for optimal, PCR-ready DNA purification from highly processed foodstuffs and PCR inhibitor-rich substances-such as cocoa-containing products-adapted protocols for the QIAGEN ${ }^{\circledR}$ QIAamp ${ }^{\circledR}$ DNA Stool Mini Kit can be utilized. For complete DNA isolation from raw foodstuffs, a protocol using the DNeasy ${ }^{\circledR}$ Plant Mini Kit is presented.
\end{abstract}

\section{INTRODUCTION}

PCR has already proved its worth as an analytical method for the detection of genetically modified organism (GMO) material in foodstuffs, through its simplicity, specificity, and sensitivity. Trace amounts of DNA are sufficient for the detection of GMO material in foodstuffs, and the deciding factor in their detection is the quality, quantity, and purity of the isolated DNA. Numerous DNA isolation methods exist in the literature, and there are also commercially produced kits available for this important pre-analytical step. DNA extraction from highly processed foods such as pastries, some breakfast cereals, ready meals, or food additives can be difficult because of the DNA-degrading action of some manufac- turing processes. For the detection of GMO material in cocoacontaining foodstuffs, another problem presents itself, namely that such foodstuffs contain high levels of plant secondary metabolites, which can lead to an irreversible inhibition of the PCR process. Such substances must be completely removed before PCR analysis can take place. In this study, two methods for the isolation of sufficient amplifiable DNA from foodstuff samples are presented using the DNeasy ${ }^{\circledR}$ Plant Mini Kit and the QIAamp ${ }^{\circledR}$ DNA Stool Mini Kit (both from QIAGEN, Hilden, Germany). We demonstrate that the DNeasy Plant Mini Kit efficiently delivers PCR-ready DNA from raw foodstuffs and processed foods and that the QIAamp DNA Stool Mini Kit can be used for PCR-ready DNA isolation from highly processed samples and foodstuffs containing cocoa and other PCR-inhibitory compounds. Both procedures can be routinely performed in any analytical laboratory.

\section{MATERIALS AND METHODS}

\section{DNA Isolation}

Samples were processed using the QIAamp DNA Stool Mini Kit and the DNeasy Plant Mini Kit. Both methods are based on silica gel membrane technology and allow an efficient extraction of complete DNA from stool samples and plant tissues, respectively. In these procedures, the cellular components of the sample are first lysed. In later steps, the DNA is bound to a membrane gel matrix, washed thoroughly, and then eluted. The DNA Stool Mini Kit Protocol contains an extra pre-purification step in which PCR inhibitors are removed. 
Table 1. Sequences of Primers Used in This Study

\begin{tabular}{|c|c|c|c|c|}
\hline Primer & $\begin{array}{l}\text { Sequence } \\
\qquad\left(5^{\prime} \rightarrow 3^{\prime}\right)\end{array}$ & $\begin{array}{l}\text { Target } \\
\text { Gene }\end{array}$ & $\begin{array}{c}\text { Length of } \\
\text { Amplified Fragment }\end{array}$ & Reference \\
\hline Lektin1 & GACGCTATTGTGACCTCCTC & Le1 (Soya lectin) & $318 \mathrm{bp}$ & This work \\
\hline Lektin6 & GAAAGTGTCAAGCTTAACAGCGACG & Le1 (Soya lectin) & & This work \\
\hline RR01 & TGGCGCCCAAAGCTTGCATGGC & $\begin{array}{c}\text { EPSPS } \\
\text { (RR Soya specific) }\end{array}$ & $356 \mathrm{bp}$ & 2 \\
\hline RR04 & CCCCAAGTTCCTAAATCTTCAAGT & $\begin{array}{c}E P S P S \\
\text { (RR Soya specific) }\end{array}$ & & 2 \\
\hline Ivr1A & CCGCTGTATCACAAGGGCTGGTACC & Ivr (Maize invertase) & $226 \mathrm{bp}$ & 1 \\
\hline Ivr1B & GGAGCCCGTGTAGAGCATGACGATC & Ivr (Maize invertase) & & 1 \\
\hline Cry1Ab & ACCATCAACAGCCGCTACAACGACC & $\begin{array}{c}\operatorname{CrylA(b)} \\
\text { (Bt-Maize specific) }\end{array}$ & $184 \mathrm{bp}$ & 1 \\
\hline Cry1As & TGGGGAACAGGCTCACGATGTCCAG & $\begin{array}{c}\operatorname{CrylA}(b) \\
\text { (Bt-Maize specific) }\end{array}$ & & 1 \\
\hline
\end{tabular}

\section{DNA Isolation Using the DNeasy Plant Mini Kit}

For DNA isolation, $100 \mathrm{mg}$ each test substance were placed in a $1.5-\mathrm{mL}$ reaction tube and processed according to the protocols supplied with the kit. For DNA isolation from highly hygroscopic samples, the amounts of buffer (AP1, AP2, and AP3) and RNase used were increased. In addition, the lysis incubation time was adjusted to individual samples. In each series of experiments, at least two controls-a water (negative) control and a positive control-were processed in parallel. Isolated DNA $(5 \mu \mathrm{L})$ was used for each reaction (species and GMO detection reactions).

\section{DNA Isolation Using the QIAamp DNA Stool Mini Kit}

For the isolation of DNA, $200 \mathrm{mg}$ each test substance were placed into a $2-\mathrm{mL}$ plastic reaction tube and processed according to the protocol for "Isolation of DNA from Stool for Pathogen Detection" in the handbook supplied with the kit. Here also, some parameters (e.g., buffer volumes and incubation times) were adapted to individual samples. As before, two controls (i.e., water and a positive control) were carried out in parallel. Isolated DNA $(5 \mu \mathrm{L})$ was used for each reaction (species and GMO detection reactions).

\section{DNA Characterization}

The approximate amount and average size of isolated DNA were determined before PCR by agarose gel electrophoresis. Isolated DNA $(20 \mu \mathrm{L})$ was loaded onto a $0.8 \%$ agarose gel and electrophoresed in $1 \times$ TAE buffer ( $40 \mathrm{mM}$ Tris-acetate, $2 \mathrm{mM}$ EDTA), pH 8.5, and visualized by ethidium bromide staining and UV transillumination (data not shown).

\section{PCR Primers}

Primers for amplification of regions of the soybean lectin gene, the maize invertase gene, and the foreign genes were in- troduced into the genetically modified variants. Delta endotoxin gene from Bacillus thuringiensis $[\operatorname{CryIA}(b)]$ and the gene for 5'-enolpyruvylshikimate-3-phosphate synthase (EPSPS) were chosen using published sequences. Sequences of primers used in this study appear in Table 1. Primers used for amplification of the soybean lectin and maize invertase genes were used as species-specific controls to show that DNA isolated was of sufficient quality and quantity to make PCR analysis possible. Primers were synthesized by Life Technologies (Karlsruhe, Germany).

\section{Standard PCR Assays}

Each amplification reaction contained $1 \times$ reaction buffer; $0.2 \mathrm{mM}$ each dATP, dCTP, dGTP, and dTTP [or dUTP for carry-over prevention by using uracil-N-glycolase (UNG) (Roche Molecular Biochemicals, Mannheim, Germany)]; $0.5 \mu \mathrm{M}$ each primer; 2 U Taq DNA Polymerase (QIAGEN); and $2 \mathrm{mM}$ $\mathrm{MgCl}_{2}$ for the soybean-specific amplifications, or $1.25 \mathrm{mM}$ $\mathrm{MgCl}_{2}$ for maize-specific amplifications. Amplification profiles were as follows: denaturation for $3 \mathrm{~min}$ at $94^{\circ} \mathrm{C} ; 50$ cycles (maize 45 cycles) of $45 \mathrm{~s}$ at $94^{\circ} \mathrm{C}, 45 \mathrm{~s}$ at $60^{\circ} \mathrm{C}$, and $25 \mathrm{~s}$ (maize $35 \mathrm{~s}$ ) at $72^{\circ} \mathrm{C}$; and a final extension of $5-10 \mathrm{~min}$ at $72^{\circ} \mathrm{C}$.

\section{Reference Reactions}

To quantify the sensitivity of the reaction, samples of soybean and maize powder containing $0.1 \%(w / w)$ genetically altered material were added to standard reactions (see above) to act as positive controls for both the species- and GMO-specific primers. Institute for Reference Materials and Measurements (IRMM)-certificated soybean and maize reference material was obtained commercially (Fluka, Munich, Germany). The concentration of DNA isolated from the $0.1 \%$ reference material samples was determined photometrically and was found to be approximately $80 \mathrm{ng} / \mu \mathrm{L}$ for soybean and $25 \mathrm{ng} / \mu \mathrm{L}$ for maize (data not shown) corresponding to between 200 (soybean) and 30 (maize) copies of genetically altered DNA 
per reaction. In addition, for each sample tested, a sample spiked with reference material was processed in parallel and probed with relevant primers to control for PCR inhibition.

\section{PCR Fragment Analysis}

Analysis of amplified DNA fragments were electrophoresed on $2 \%$ agarose gels in $1 \times$ TAE buffer, and bands were visualized by ethidium bromide staining and UV transillumination.

\section{RESULTS}

\section{Successful Amplification of DNA Isolated Using the DNeasy Plant Mini Kit}

DNA was obtained in concentrations ranging from 0.9 $\mu \mathrm{g} / 100 \mathrm{mg}$ test sample (tofu) to $136 \mu \mathrm{g} / 100 \mathrm{mg}$ test sample (soya flour) (data not shown). PCR assay using gene-specific primers showed that maize and soybean species-specific reporter gene fragments, and also fragments from the Roundup Ready $^{\mathrm{TM}}$ (Monsanto, St. Louis, MO, USA)-specific EPSPS and Bt-176 "Maximizer" Maize (Novartis, Basel, Switzerland)-specific $\operatorname{CryIA}(b)$ genes, could be amplified from DNA isolated using the DNeasy Plant Mini Kit (Figure 1, Figure 2, and Table 2). The presence of EPSPS and CryIA(b) fragments indicates that a proportion of the tested foodstuff's soybean or maize content is derived from genetically modified material.

\section{Successful Amplification of DNA Isolated Using the QIAamp DNA Stool Mini Kit}

The QIAamp DNA Stool Mini Kit was developed to allow extraction of PCR-competent DNA from stool, a material rich in PCR-inhibitory substances. It has been found that cocoacontaining products also contain PCR inhibitors, making PCR

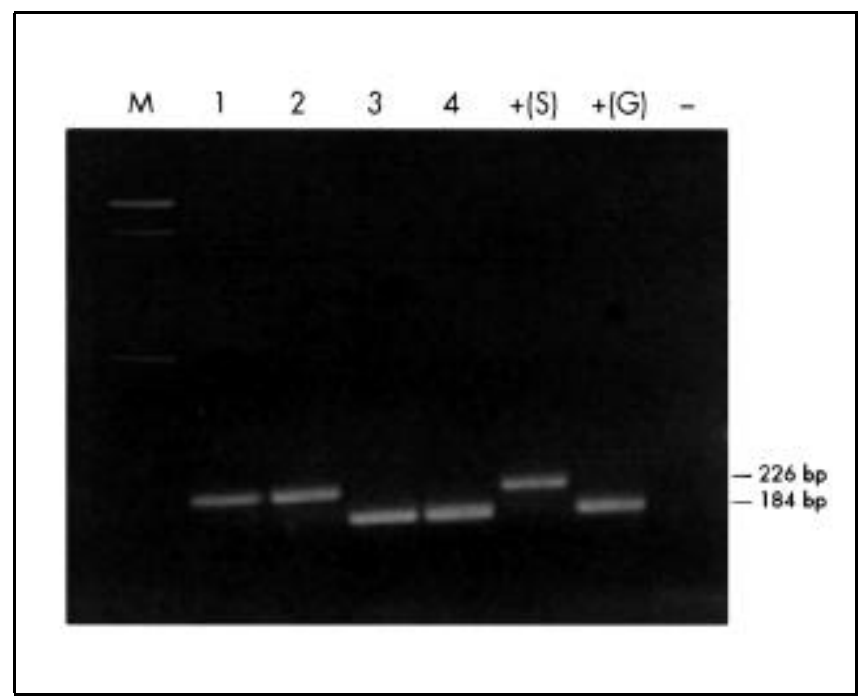

Figure 1. Screening of maize products for traces of GMO Bt-176 "Maximizer" Maize. Detection of: lanes 1 and 2, species-specific (invertase); lanes 3 and 4, GMO-specific [CryIA(b)] gene fragments by PCR. DNA was isolated using the DNeasy Plant Mini Kit. Samples were: lanes 1 and 3, corn flour; lanes 2 and 4, cornmeal. Sizes and genes of origin of amplified fragments are indicated to the right of the figure. M, 100-bp ladder (LTI, Eggensheim, Germany). $+(S)$, positive control for species. $+(G)$, positive control for GMO material. -, negative control (water). analysis of such foodstuffs difficult. In the QIAamp DNA Stool Mini Kit procedure, substances that may inhibit the reaction are removed by reaction and precipitation with Inhibi$\mathrm{tEX}^{\mathrm{TM}}$ after sample treatment with Buffer ASL. Use of this procedure allowed amplification of soybean lectin reporter gene fragments and Roundup Ready-specific EPSPS gene fragments from a variety of PCR inhibitor-containing samples (Figure 3 and Table 2). DNA was obtained in concentrations ranging from $0.2 \mu \mathrm{g} / 100 \mathrm{mg}$ test sample (praline chocolates) to $3.3 \mu \mathrm{g} / 100 \mathrm{mg}$ test sample (chocolate muesli bar) (data not shown). Reference material-spiked samples (which were all positive in PCR) showed that any species- or GMO-specific negative results were not due to inhibition of PCR.

It is assumed that samples that gave negative results in both the species- and GMO-specific detection contained very little or no DNA or that DNA present was severely fragmented because of the high level of processing.

\section{DISCUSSION}

Amplification of species-specific gene fragments in most samples tested demonstrates that DNA of integrity sufficient for PCR analysis can be purified using the described techniques. As a general rule, it was found that the DNeasy Plant Mini Kit was best suited to isolation of DNA from less processed foodstuffs, such as corn meal and corn flour, and that the QIAamp DNA Stool Mini Kit was best suited to isolation of DNA from highly processed samples that might also contain PCR-inhibitory substances. Spiking experiments showed that PCR-inhibitory substances found in some foodstuffs (notably cocoa-containing samples) were efficiently removed during the QIAamp DNA Stool Mini Kit procedure. The amplification of GMO-derived gene fragments in some samples tested also shows the suitability of these procedures for the analysis and detection of GMO material in foodstuffs.

As of April 2000, a European Union directive requires that, in addition to products containing genetically modified

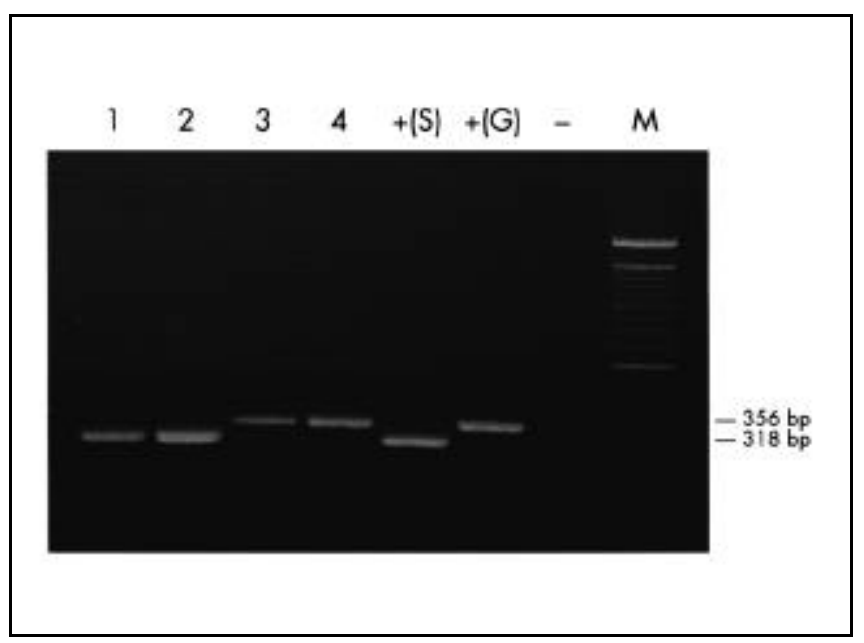

Figure 2. Screening of soybean products for traces of GMO Roundup Ready Soybean. Detection of: lanes 1 and 2, species-specific (lectin); lanes 3 and 4, GMO-specific (EPSPS) gene fragments by PCR. DNA was isolated using the DNeasy Plant Mini Kit. Samples were: lanes 1 and 3, tofu; lanes 2 and 4, biscuits. Sizes and genes of origin of amplified fragments are indicated to the right of the figure. M, 100-bp ladder. $+(S)$, positive control for species. $+(\mathrm{G})$, positive control for GMO material. -, negative control (water). 
Table 2. Species- and GMO-Specific Gene Detection by PCR Using DNA Isolated from the Indicated Samples

\begin{tabular}{|c|c|c|c|c|}
\hline Sample & $\begin{array}{l}\text { Target Genes } \\
\text { Species/ } \\
\text { GMO Detection }\end{array}$ & Spiked Sample & $\begin{array}{l}\text { Species-Specific } \\
\text { Detection }\end{array}$ & $\begin{array}{c}\text { GMO-Specific } \\
\text { Detection }\end{array}$ \\
\hline Corn floura & Maize invertase/CryIA(b) & $+/+$ & + & + \\
\hline Corn meala & Maize invertase/CryIA(b) & $+/+$ & + & + \\
\hline Biscuitsa & Soya lectin/EPSPS & $+/+$ & + & + \\
\hline Soya floura & Soya lectin/EPSPS & $+/+$ & + & - \\
\hline Tofua & Soya lectin/EPSPS & $+/+$ & + & + \\
\hline Soya proteina & Soya lectin/EPSPS & $+/+$ & + & + \\
\hline Chocolate creamb & Soya lectin/EPSPS & $+/+$ & - & - \\
\hline Milk chocolateb & Soya lectin/EPSPS & $+/+$ & - & - \\
\hline Nougat waffle biscuitb & Soya lectin/EPSPS & $+/+$ & + & - \\
\hline Chocolate muesli barb & Soya lectin/EPSPS & $+/+$ & + & + \\
\hline Praline chocolatesb & Soya lectin/EPSPS & $+/+$ & - & - \\
\hline Chocolate biscuits ${ }^{b}$ & Soya lectin/EPSPS & $+/+$ & + & - \\
\hline Chocolate diet drinkb & Soya lectin/EPSPS & $+/+$ & + & + \\
\hline Miso paste $b$ & Soya lectin/EPSPS & $+/+$ & + & + \\
\hline Taco shells ${ }^{b}$ & Maize invertase/CryIA(b) & $+/+$ & + & + \\
\hline Chocolate cerealb & Maize invertase/CryIA(b) & $+/+$ & + & + \\
\hline \multicolumn{5}{|c|}{$\begin{array}{l}\text { Optimal results were obtained with athe DNeasy Plant Mini Kit or bthe QIAamp DNA Stool Mini Kit. +, target gene could be } \\
\text { amplified (positive result). -, target gene could not be amplified (negative result). PCR inhibition was excluded by spiking } \\
\text { experiments (see text). }\end{array}$} \\
\hline
\end{tabular}

ingredients, foodstuffs containing food additives derived from genetically modified sources must be labeled. Therefore, the requirement for procedures allowing fast, easy, and reliable GMO testing will increase. The two procedures outlined here will facilitate such testing, especially in the case of products

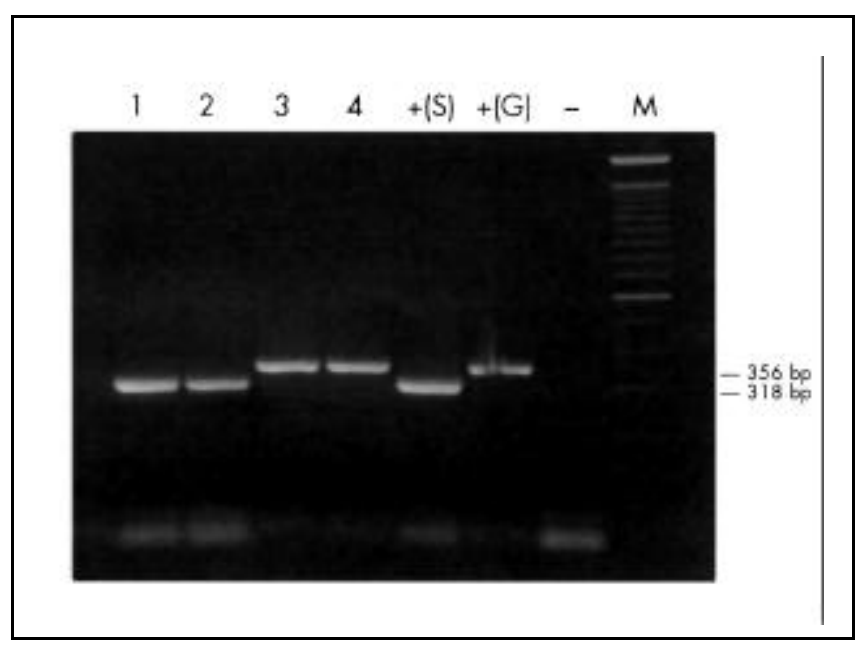

Figure 3. Screening of highly processed foodstuffs for traces of GMO Roundup Ready Soybean. Detection of: lanes 1 and 2, species-specific (lectin); lanes 3 and 4, GMO-specific (EPSPS) gene fragments by PCR. DNA was isolated using the QIAamp DNA Stool Mini Kit. Samples were: lanes 1 and 3, chocolate-flavored diet drink; lanes 2 and 4, miso paste. Sizes and genes of origin of amplified fragments are indicated to the right of the figure. M, 100-bp ladder. $+(S)$, positive control for species. $+(G)$, positive control for GMO material. -, negative control (water). that would otherwise be difficult to analyze because of a high level of processing or PCR-inhibitory substances.

\section{ACKNOWLEDGMENTS}

The authors would like to thank Sandra Schlotter (Labor $\mathrm{L}+\mathrm{S}$ AG), Monika Taruttis and Markus Basse (QIAGEN $\mathrm{GmbH})$ for their excellent technical assistance, and Barbara Walter-Kimmerle (QIAGEN $\mathrm{GmbH}$ ) for critical reading of the manuscript.

\section{REFERENCES}

1.Ehlers, B., E. Strauch, M. Goltz, D. Kubsch, H. Wagner, H. Maidhof, J. Bendiek, B. Appel, and H-J. Buhk. 1997. Nachweis gentechnischer Veränderungen in Mais mittels PCR. Bundesgesundhbl. 4:118-121.

2.Studer, E., C. Rhyner, J. Lüthy, and P. Hübner. 1998. Quantitative com petitive PCR for the detection of genetically modified soybean and maize. Z. Lebensm. Unters. Forsch. 207:207-213.

Address correspondence to Dr. Markus Sprenger-Haußels, QIAGEN GmbH, Max-Volmer-Strasse 4, 40724 Hilden, Germany.e-mail: m.sprenger-haussels@de.qiagen.com

For reprints of this or any other article, contact Reprints@BioTechniques.com 